\title{
Evaluation of in vitro antioxidants activities, hepatoprotective and haematological effects of ethanol extract of Anthocleista vogelii stem bark (AVSB) on carbon tetrachloride $\left(\mathrm{CCl}_{4}\right)$ induced rats
}

\author{
Robert UROKO $^{1 *}$ (D) , Chinedu NWUKE ${ }^{2}$ (D) , Amarachi AGBAFOR ${ }^{1}$ (D), Josephat OKWOR 2 (D) \\ 1 Department of Biochemistry, College of Natural Sciences, Michael Okpara University of Agriculture, Umudike, Abia \\ State, Nigeria, PMB 7267. \\ 2 Laboratory Unit, Department of Biochemistry, College of Natural Sciences, Michael Okpara University of \\ Agriculture, Umudike, Abia State, Nigeria, PMB 7267. \\ * Corresponding Author. E-mail: ir.uroko@mouau.edu.ng (R.U.); Tel. +234-806-591 4471
}

Received: 30 December 2020 / Revised: 23 March 2020/ Accepted: 27 March 2020

\begin{abstract}
Anthocleista vogelii stem bark extract (AVSB) is used as a hepatoprotective protective and blood-boosting agent locally without any scientific evidence. This study evaluated the in vitro antioxidants activity, hepatoprotective and haematological effects of ethanol extract of AVSB on carbon tetrachloride $\left(\mathrm{CCl}_{4}\right)$ induced rats. Thirty rats distributed into 5 groups $(\mathrm{n}=6)$ were used. Group 1 was the normal control rats without $\mathrm{CCl}_{4}$ induction, group 2 was the $\mathrm{CCl}_{4}$ control $\left(\mathrm{CCl}_{4}\right.$ induced untreated rats) while groups $3-6$ were $\mathrm{CCl}_{4}$ induced rats treated with $100 \mathrm{mg} / \mathrm{kg} / \mathrm{day}$ of silymarin, 100, 200 and $500 \mathrm{mg} / \mathrm{kg} /$ day of AVSB respectively for 14 days. The results indicated high levels of total phenols, flavonoid, vitamin E, vitamin C, $\beta$-carotene and lycopene in the AVSB. The AVSB exhibited a dose-dependent increase in ferric reducing antioxidant power, DPPH and nitric oxide radicals scavenging activities similar to vitamin $\mathrm{C}$, rutin and curcumin respectively. The $\mathrm{CCl}_{4}$ induction significantly $(\mathrm{P}<0.05)$ elevated total bilirubin concentrations, serum ALT, AST and ALP activities and significantly $(\mathrm{P}<0.05)$ decreased PCV, $\mathrm{RBC}, \mathrm{WBC}$, platelet counts, and $\mathrm{Hb}$, total protein and albumin concentrations and caused liver necrosis in the untreated rats relative to the normal control. Treatment with AVSB significantly reversed the altered serum ALT, AST and ALP activities, total bilirubin, total protein, albumin and $\mathrm{Hb}$ concentrations including haematological indices and liver histomorphology to normal compared with the $\mathrm{CCl}_{4}$ control. The findings of this study indicated that the AVSB is rich in antioxidant components, in vitro antioxidant activity, and possesses hepatoprotective and improves haematological indices
\end{abstract}

KEYWORDS: Anthocleista vogelii; antioxidant activity; carbon tetrachloride; hepatoprotective; haematological indices.

\section{INTRODUCTION}

The liver is a very active organ responsible for the metabolism and detoxification of drugs and xenobiotics in the body, these predispose it to injury or oxidative attack from reactive metabolites generated from phagocytes, metabolism of prooxidants and incomplete transfer of electrons to oxygen in the electron transport chain. Insufficient amounts of antioxidants in the body to scavenge free radicals leads to oxidative stress, which could cause harmful effects on membranes, DNA, tissues, organs and other biomolecules [1]. It has been reported that oxidative stress could cause alcoholic liver disease and other liver disorders [2]. Plant extracts rich in antioxidants like phenols, flavonoids, $\beta$-carotene, vitamins $C$ and $E$ are capable of scavenging excess free radicals and reduce their levels to minimal concentrations and eventually ameliorate oxidative stress-induced tissues and cellular damage. They prevent oxidative stress-induced tissue damage because of their antioxidant properties that enable them, chelate metals, and reduce oxidants through the donation of hydrogen atoms and quenching of singlet oxygen [3]. Liver injury aside from damaging the integrity of the hepatocytes, impairs liver functions like protein synthesis, detoxification and metabolic functions carried out by the liver. To prevent liver damage and maintain normal liver functions, the health status of the liver could be indirectly monitored by measuring the serum activities of aspartate transaminase (AST), lactate dehydrogenase (LDH), alanine transaminase (ALT), and alkaline phosphatase (ALP) addition to total protein and bilirubin concentrations.

How to cite this article: Uroko R, Nwuke C, Agbafor A, Okwor J. Evaluation of in vitro antioxidants activities, hepatoprotective and haematological effects of ethanol extract of Anthocleista vogelii stem bark (AVSB) on carbon tetrachloride $\left(\mathrm{CCl}_{4}\right)$ induced rats. J Res Pharm. 2020; $25(3)$ : 258-270. 
Carbon tetrachloride is a well-known hepatotoxicant employed for the induction of liver injury in animals to enable investigations of hepatoprotective efficacy of synthetic drugs and traditional medicines against hepatic diseases. It induces hepatic injury and sometimes kidney injury by the oxidative attack of trichloromethyl $\left(\mathrm{CCl}_{3} \bullet\right)$ and trichloromethyl peroxyl $\left(\mathrm{Cl}_{3} \mathrm{COO} \bullet\right)$ radicals produced from its metabolic break down in the liver by the cytochrome P450 enzymes [4,5]. The endogenous antioxidant enzymes and nonenzymatic antioxidants present in the body fight to prevent oxidative stress and their associated adverse health effects but are overwhelmed under the condition of oxidative stress and leave the individual vulnerable to oxidative attack and damage. Treatment with antioxidant drugs like silymarin and plant extracts with high antioxidant activities reduce oxidative stress but the use of medicinal plants rich in antioxidant components and activities are on the increase because they have been found to possess a low risk of adverse health effects, cheap and readily available.

Anthocleista vogelii Planch commonly called the English cabbage tree belongs to the family of Loganiaceae and is used in traditional medicine because of its high therapeutic potentials against many diseases. A. vogelii extracts are useful in the treatment of various diseases including diabetes, fever, malaria, hypertension, stomach aches, indigestion, obesity, oxidative stress and bacterial infections such as typhoid and syphilis [6, 7]. The root and stem bark of $A$. vogelii possess pharmacological activities such as antiviral activities, anti-snake venom, anti-oedema and induce contraction for labour and abortion and reduce menstrual cycle pain [6]. The mixture of $A$. vogelii leaves and stem bark is a common contraceptive, anti- infertility and hepatoprotective herbal formulation in local traditional medicine, in Nigeria but there are little pieces of evidence to support these claims. The medicinal properties of $A$. vogelii extract are due partly to the pharmacological activities of the phytochemicals like glycosides, steroids, saponins, terpenoids, alkaloids and flavonoids found in the extract $[8,9]$. This study evaluated the in vitro antioxidants activity, hepatoprotective and haematological effects of ethanol extract of $A$. vogelii stem bark (AVSB) on carbon tetrachloride $\left(\mathrm{CCl}_{4}\right)$ induced rats. The results of this study help in further understanding the medicinal properties of $A$. vogelii and validations of some of its therapeutic claims by local traditional medicine users.

\section{RESULTS}

\subsection{Antioxidant contents in the AVSB}

The data in table 1 indicated high levels of antioxidant constituents in the AVSB with the total phenolic and lycopene as the highest and least available antioxidant constituents in the AVSB respectively. Flavonoids were present in high concentration but lower than the total phenolic content. The trends of antioxidant levels in AVSB indicated that total phenolic $>$ flavonoid $>$ vitamin $E>$ vitamin $C>\beta$-carotene $>$ lycopene.

Table 1. Antioxidant constituents of AVSB.

\begin{tabular}{lc}
\hline Antioxidant constituents & Bioavailability $(\mathbf{m g} / \mathbf{1 0 0 g})$ \\
\hline Total phenolic & $3120.76 \pm 5.10$ \\
Flavonoid & $1175.54 \pm 7.53$ \\
$\beta$-carotene & $1.58 .52 \pm 0.01$ \\
Lycopene & $0.88 .40 \pm 0.01$ \\
Vitamin E & $189.32 \pm 0.05$ \\
Vitamin C & $102.32 \pm 0.87$ \\
\hline Values are presented as mean \pm standard deviation $(\mathrm{n}=3)$
\end{tabular}

\subsection{Ferric reducing antioxidant power (FRAP) of AVSB}

The AVSB indicated a dose-dependent increase in ferric reducing antioxidant power similar to vitamin $\mathrm{C}$ and rutin but much lower than either vitamin or rutin (Figure 1). The AVSB showed the highest ferric reducing antioxidant power at $1 \mathrm{mg} / \mathrm{ml}$ concentration like the rutin and vitamin $\mathrm{C}$ respectively.

\subsection{DPPH (2,2-diphenyl-1-picrylhydrazyl) radical scavenging activities of AVSB}

In Figure 2, the ethanol extract of AVSB exhibited dose-dependent 2,2-diphenyl-1-picrylhydrazyl (DPPH) radical scavenging activities in comparison with the DPPH scavenging activities of vitamin C (standard antioxidant). The AVSB had the highest percentage DPPH inhibition of $54.36 \%$ at $100 \mu \mathrm{g} / \mathrm{ml}$ concentration far below the $89.16 \%$ recorded for vitamin $C$ at the same concentration. The concentrations of AVSB and vitamin C required to achieve 50\% inhibition of DPPH radicals (IC50) were 49 and $36 \mu \mathrm{g} / \mathrm{ml}$ respectively. 


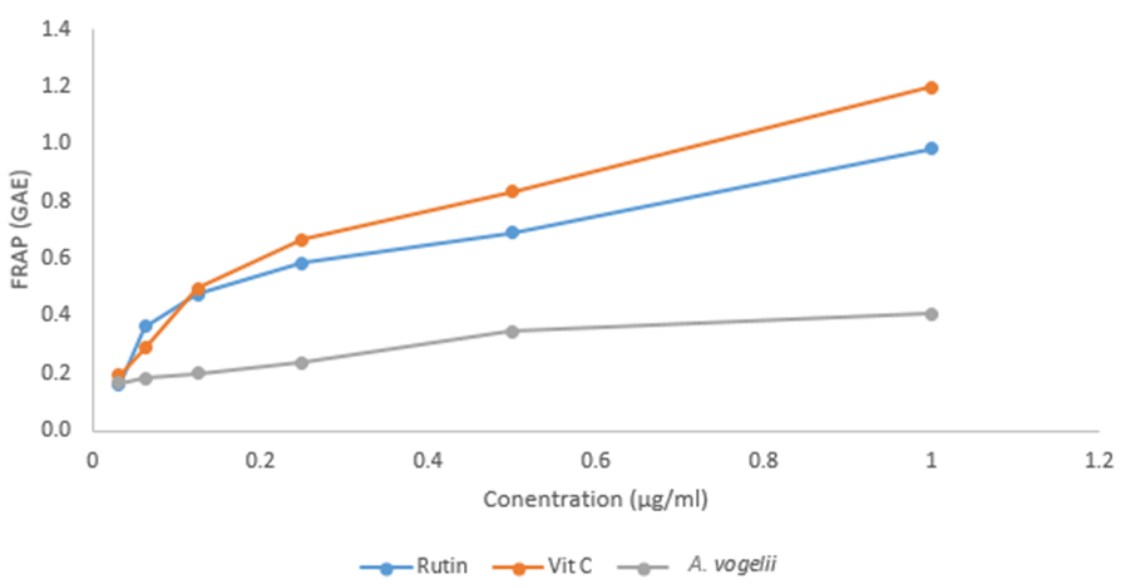

Figure 1. Ferric reducing antioxidant power of $A$. vogelii, vitamin $C$ and rutin.

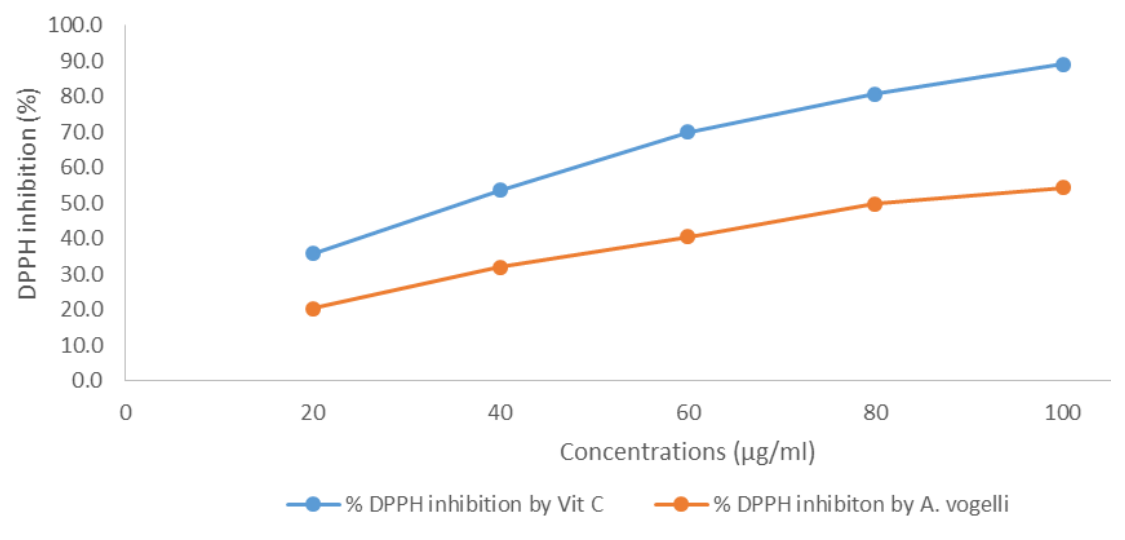

Figure 2. DPPH (2,2-diphenyl-1-picrylhydrazyl) radical scavenging activities of AVSB.

\subsection{Nitric oxide scavenging activities of AVSB}

The data in Figure 3 indicated a dose-dependent increase in nitric oxide scavenging activities of the AVSB relative to curcumin a standard antioxidant compound. The least $(4.14 \%)$ and highest $(55.45 \%)$ nitric oxide inhibition by the AVSB occurred at 20 and $100 \mu \mathrm{g} / \mathrm{ml}$ respectively, which were relatively lower than 17.44 and $82.64 \%$ exhibited by curcumin at the corresponding concentrations. The AVSB had an IC50 (concentration required to achieve $50 \%$ inhibition of nitric oxide) of $62.80 \mu \mathrm{g} / \mathrm{ml}$, which was higher than the IC50 value of $56 \mu \mathrm{g} / \mathrm{ml}$ recorded for curcumin.

\subsection{Effects of AVSB on the alanine transaminase (ALT) activities of $\left(\mathrm{CCl}_{4}\right.$ induced rats}

The carbon tetrachloride $\left(\mathrm{CCl}_{4}\right)$ induced rats showed significantly $(\mathrm{P}<0.05)$ elevated alanine transaminase (ALT) activities when compared with the normal control rats, with the $\mathrm{CCl}_{4}$ control rats having the highest ALT activities relative to the $\mathrm{CCl}_{4}$ induced rats treated with silymarin and AVSB respectively (Figure 4). The $\mathrm{CCl}_{4}$ induced rats treated with $100 \mathrm{mg} / \mathrm{kg} / \mathrm{d}$ of silymarin, 200 and $500 \mathrm{mg} / \mathrm{kg} / \mathrm{d}$ of AVSB respectively showed significant $(\mathrm{P}<0.05)$ reductions in the ALT activities in comparison with the $\mathrm{CCl}_{4}$ control. Besides, the $\mathrm{CCl}_{4}$ induced rats treated with $100 \mathrm{mg} / \mathrm{kg} / \mathrm{d}$ of AVSB showed no significant $(\mathrm{P}>0.05)$ reduction in ALT activities when compared with the $\mathrm{CCl}_{4}$ control.

\subsection{Effects of AVSB on the aspartate transaminase (AST) activities of $\mathrm{CCl}_{4}$ induced rats}

The $\mathrm{CCl}_{4}$ induction caused significant $(\mathrm{P}<0.05)$ increases in the aspartate transaminase $(\mathrm{AST})$ activities in the rats relative to the normal control (Figure 5). Treatment of the $\mathrm{CCl}_{4}$ induced rats with $100 \mathrm{mg} / \mathrm{kg} / \mathrm{d}$ of silymarin, 200 and $500 \mathrm{mg} / \mathrm{kg} / \mathrm{d}$ of AVSB, respectively significantly $(\mathrm{P}<0.05)$ decreased the AST activities of the respective rat groups relative to the $\mathrm{CCl}_{4}$ control. The $\mathrm{CCl}_{4}$ induced rats treated with $200 \mathrm{mg} / \mathrm{kg} / \mathrm{d}$ of AVSB showed no significant $(\mathrm{P}>0.05)$ increase in the AST activity when compared with the normal control while the $\mathrm{CCl}_{4}$ induced rats treated with $500 \mathrm{mg} / \mathrm{kg} / \mathrm{d}$ of AVSB showed significant $(\mathrm{P}<0.05)$ reduction in the AST activity relative to the normal control. Besides, the $\mathrm{CCl}_{4}$ induced rats treated with $100 \mathrm{mg} / \mathrm{kg} / \mathrm{day}$ of AVSB showed no significant $(\mathrm{P}>0.05)$ reduction in the AST activity when compared with $\mathrm{CCl}_{4}$ control. 


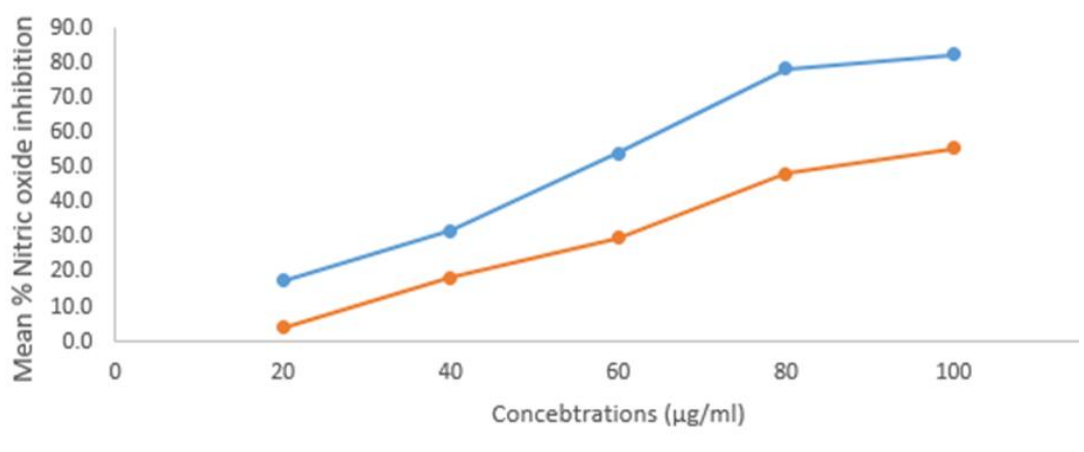

$\multimap \%$ inhibition of Nitric oxide by cucumin $\quad \longrightarrow \%$ inhibition of Nitric oxide by A. vogelli

Figure 3. Percentage of nitric oxide inhibition by AVSB.

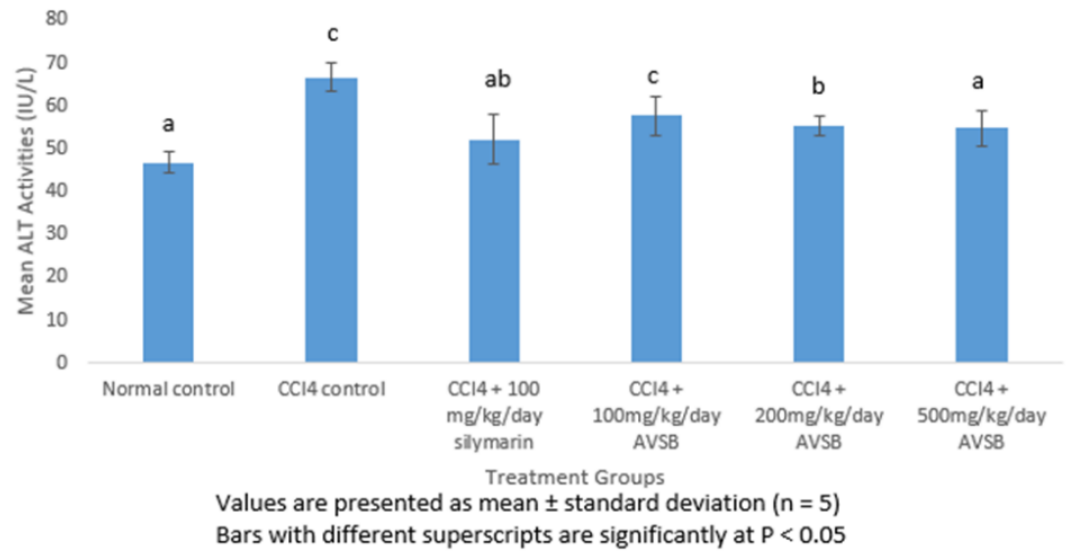

Figure 4. Alanine transaminase activities of $\mathrm{CCl}_{4}$ induced rats treated with AVSB.

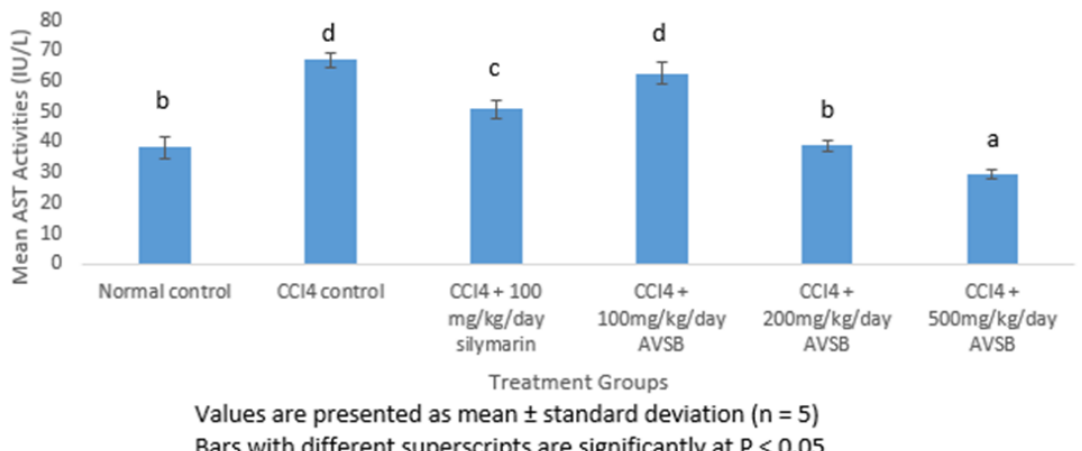

Figure 5. Aspartate transaminase activities of $\mathrm{CCl}_{4}$ induced rats treated with AVSB

\subsection{Effects of AVSB on the alkaline phosphatase (ALP) activities of $\mathrm{CCl}_{4}$ induced rats}

The data in Figure 6 indicated significantly $(\mathrm{P}<0.05)$ increases in the alkaline phosphatase (ALP) activities of the $\mathrm{CCl}_{4}$ induced rats when compared with the normal control. Treatment of the $\mathrm{CCl}_{4}$ induced rats with graded doses of AVSB caused dose-dependent significant $(\mathrm{P}<0.05)$ decreases in the ALP activities relative to the $\mathrm{CCl}_{4}$ control. The ALP activity of the $\mathrm{CCl}_{4}$ induced rats treated with $100 \mathrm{mg} / \mathrm{kg} / \mathrm{d}$ of silymarin decreased significantly $(\mathrm{P}<0.05)$ when compared with the $\mathrm{CCl}_{4}$ control but significantly $(\mathrm{P}<0.05)$ higher than the normal control. The $\mathrm{CCl}_{4}$ induced rats treated with $500 \mathrm{mg} / \mathrm{kg} / \mathrm{d}$ of AVSB had the highest reduction in the ALP activity been non-significantly higher than the normal control.

\subsection{Effects of AVSB on the total protein concentrations of $\mathrm{CCl}_{4}$ induced rats}

The $\mathrm{CCl}_{4}$ induction caused significant $(\mathrm{P}<0.05)$ reductions in the total protein concentrations of the rats as indicated in the $\mathrm{CCl}_{4}$ control when compared with the normal control (Figure 7). The $\mathrm{CCl}_{4}$ induced rats 
treated with $100 \mathrm{mg} / \mathrm{kg} / \mathrm{d}$ of silymarin and graded doses of AVSB respectively indicated a significant $(\mathrm{P}<$ 0.05) increase in the total protein concentrations when compared with the $\mathrm{CCl}_{4}$ control with that of the $\mathrm{CCl}_{4}$ induced rats treated with $500 \mathrm{mg} / \mathrm{kg} / \mathrm{d}$ been significantly $(\mathrm{P}<0.05)$ elevated relative to the normal control.

\subsection{Effects of AVSB on the albumin concentrations of $\mathrm{CCl}_{4}$ induced rats}

The results in Figure 8 showed that $\mathrm{CCl}_{4}$ induction caused significant $(\mathrm{P}<0.05)$ reductions in the serum albumin concentrations of the $\mathrm{CCl}_{4}$ induced rats as indicated in the $\mathrm{CCl}_{4}$ control when compared with normal. The albumin concentrations of the $\mathrm{CCl}_{4}$ induced rats treated with $100 \mathrm{mg} / \mathrm{kg} / \mathrm{d}$ of silymarin, 100 and 200 $\mathrm{mg} / \mathrm{kg} / \mathrm{d}$ of AVSB respectively showed significant $(\mathrm{P}<0.05)$ increases when compared with the $\mathrm{CCl}_{4}$ control and no significant $(\mathrm{P}>0.05)$ relative to the normal control. Also, the $\mathrm{CCl}_{4}$ induced rats treated with 500 $\mathrm{mg} / \mathrm{kg} / \mathrm{d}$ of AVSB showed a significant $(\mathrm{P}<0.05)$ increase in the albumin concentrations when compared to the normal control, $\mathrm{CCl}_{4}$ control and silymarin treated groups respectively.

\subsection{Effects of AVSB on the total bilirubin concentrations of $\mathrm{CCl}_{4}$ induced rats}

The total bilirubin concentrations in Figure 9 indicated that $\mathrm{CCl}_{4}$ induction significantly $(\mathrm{P}>0.05)$ elevated total bilirubin concentrations in the $\mathrm{CCl}_{4}$ control when compared with normal control. The $\mathrm{CCl}_{4}$ induced rats treated with $100 \mathrm{mg} / \mathrm{kg} / \mathrm{d}$ of silymarin, and graded doses of the AVSB respectively showed a significant $(\mathrm{P}<0.05)$ decrease in the total bilirubin concentration when compared with $\mathrm{CCl}_{4}$ control but significantly $(\mathrm{P}<0.05)$ higher than the normal control.

\subsection{Effects of AVSB on the haematological indices of $\mathrm{CCl}_{4}$ induced rats}

The percentage packed cell volume (PCV) in Table 2 indicated significant $(\mathrm{P}<0.05)$ reductions in the $\mathrm{PCV}$ of the $\mathrm{CCl}_{4}$ induced rats relative to the normal control. However, the $\mathrm{CCl}_{4}$ induced rats treated with graded doses of AVSB showed no significant $(\mathrm{P}>0.05)$ decreases in the PCV when compared with the normal control and $\mathrm{CCl}_{4}$ control respectively while the $\mathrm{CCl}_{4}$ induced rats treated with $100 \mathrm{mg} / \mathrm{kg} / \mathrm{d}$ of silymarin indicated no significant $(\mathrm{P}>0.05)$ increase in $\mathrm{PCV}$ relative to the normal control.

The white blood cell (WBC) counts of the $\mathrm{CCl}_{4}$ control, $\mathrm{CCl}_{4}$ induced rats treated with $100 \mathrm{mg} / \mathrm{kg} / \mathrm{d}$ of silymarin, and $500 \mathrm{mg} / \mathrm{kg} / \mathrm{d}$ of the AVSB respectively significantly $(\mathrm{P}<0.05)$ decreased when compared with the normal control (Table 2). However, the $\mathrm{CCl}_{4}$ induced rats treated with 100 and $200 \mathrm{mg} / \mathrm{kg} / \mathrm{d}$ of AVSB respectively showed no significant $(\mathrm{P}>0.05)$ increase in the WBC counts relative to the normal control. The rats induced $\mathrm{CCl}_{4}$ and treated with 100 and $200 \mathrm{mg} / \mathrm{kg} / \mathrm{d}$ of AVSB respectively showed a significant $(\mathrm{P}<0.05)$ increase in the WBC counts when compared with the $\mathrm{CCl}_{4}$ control. Besides, the $\mathrm{CCl}_{4}$ induced rats treated with $100 \mathrm{mg} / \mathrm{kg} / \mathrm{d}$ of silymarin and $500 \mathrm{mg} / \mathrm{kg} / \mathrm{d}$ of AVSB, respectively showed significant $(\mathrm{P}<0.05)$ decreases in the WBC counts relative to the $\mathrm{CCl}_{4}$ control.

The red blood cell $(\mathrm{RBC})$ counts in Table 2 indicated a significant $(\mathrm{P}<0.05)$ decrease in the RBC counts of the $\mathrm{CCl}_{4}$ induced rats $\left(\mathrm{CCl}_{4}\right.$ control) relative to the normal control rats. The $\mathrm{CCl}_{4}$ induced rats treated with $100 \mathrm{mg} / \mathrm{kg} / \mathrm{d}$ of silymarin and $500 \mathrm{mg} / \mathrm{kg} / \mathrm{d}$ of AVSB respectively showed a significant $(\mathrm{P}<0.05)$ increase in $\mathrm{RBC}$ counts when compared with the $\mathrm{CCl}_{4}$ control. However, the $\mathrm{CCl}_{4}$ induced rats treated with 100 and 200 $\mathrm{mg} / \mathrm{kg} / \mathrm{d}$ of AVSB respectively showed no significant $(\mathrm{P}>0.05)$ increase in $\mathrm{RBC}$ counts relative to the $\mathrm{CCl}_{4}$ control.

In Table 2, the haemoglobin $(\mathrm{Hb})$ concentrations of $\mathrm{CCl}_{4}$ induced untreated rats $\left(\mathrm{CCl}_{4}\right.$ control) showed a significant $(\mathrm{P}<0.05)$ decreased when compared with the normal control. The $\mathrm{CCl}_{4}$ induced rats treated with $100 \mathrm{mg} / \mathrm{kg} / \mathrm{d}$ of silymarin, 200 and $500 \mathrm{mg} / \mathrm{kg} / \mathrm{d}$ of AVSB respectively showed significant $(\mathrm{P}<0.05)$ increase in $\mathrm{Hb}$ concentrations when compared with the $\mathrm{CCl}_{4}$ control and no significant $(\mathrm{P}>0.05)$ increase in $\mathrm{Hb}$ concentration relative to the normal control. Besides the $\mathrm{CCl}_{4}$ induced rats treated with $100 \mathrm{mg} / \mathrm{kg} / \mathrm{d}$ of AVSB showed no significant $(\mathrm{P}>0.05)$ increase in $\mathrm{Hb}$ concentration when compared with $\mathrm{CCl}_{4}$ control.

The $\mathrm{CCl}_{4}$ induced untreated rats in Table 2 indicated a significant $(\mathrm{P}<0.05)$ decrease in the platelet count when compared with the normal control. The platelet counts of $\mathrm{CCl}_{4}$ induced rats treated with silymarin and graded doses of AVSB respectively showed a significant $(\mathrm{P}<0.05)$ increase when compared with the $\mathrm{CCl}_{4}$ control. The $\mathrm{CCl}_{4}$ induced rats treated with $100 \mathrm{mg} / \mathrm{kg} / \mathrm{d}$ of silymarin, 100, 200 and $500 \mathrm{mg} / \mathrm{kg} / \mathrm{d}$ of AVSB respectively showed no significant $(\mathrm{P}>0.05)$ decreases in platelet counts relative to the normal control. 


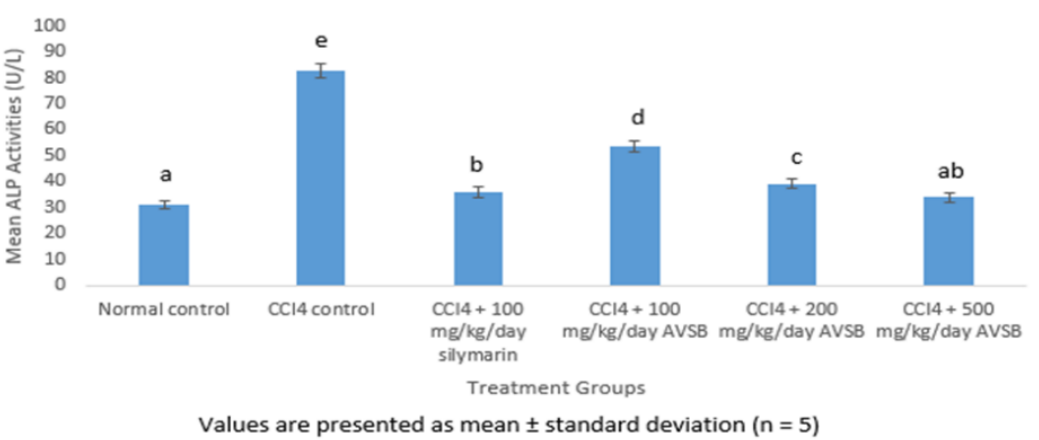

Bars with different superscripts are significantly at $\mathrm{P}<0.05$

Figure 6. Alkaline phosphatase activities of $\mathrm{CCl}_{4}$ induced rats treated with AVSB.

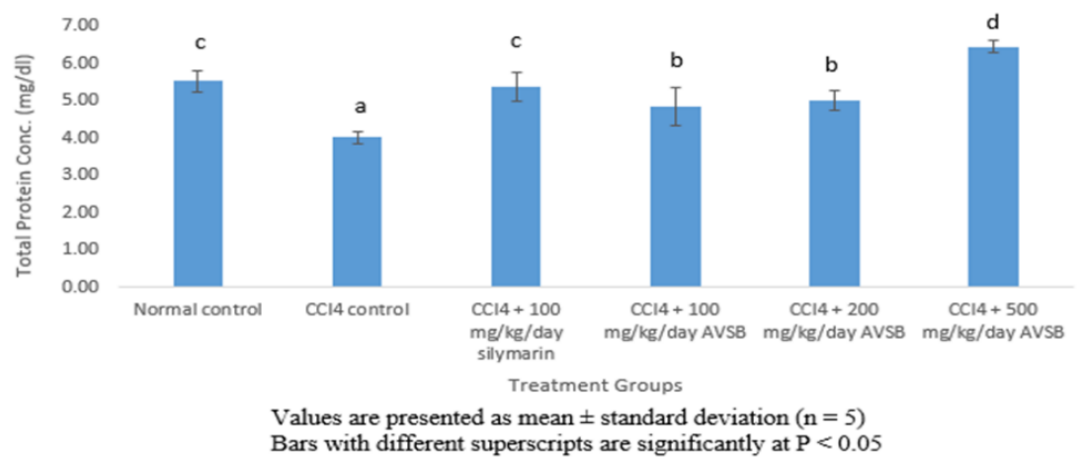

Figure 7. Total protein concentrations of $\mathrm{CCl}_{4}$ induced rats treated with AVSB.

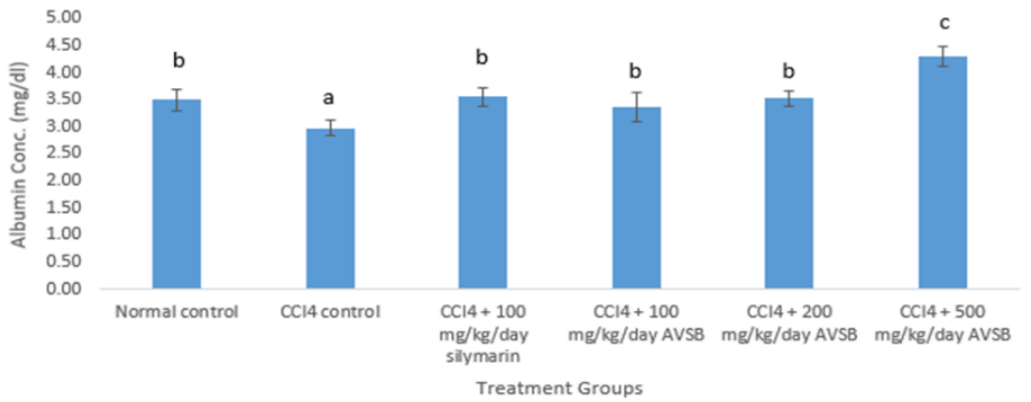

Values are presented as mean \pm standard deviation $(n=5)$ Bars with different superscripts are significantly at $\mathrm{P}<0.05$

Figure 8. Albumin concentrations of $\mathrm{CCl}_{4}$ induced rats treated with AVSB.

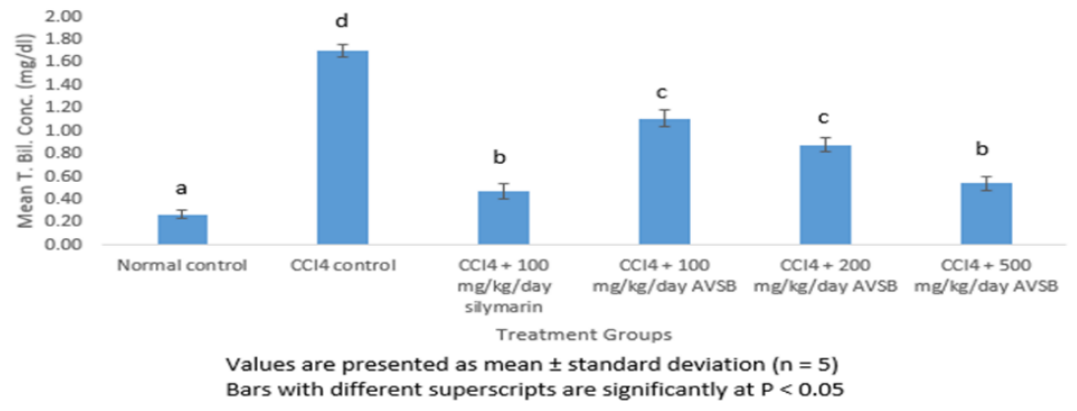

Figure 9. Total bilirubin concentrations of $\mathrm{CCl}_{4}$ induced rats treated with AVSB. 
Table 2. Haematological indices of carbon tetrachloride-induced rats treated with AVSB.

\begin{tabular}{lccccc}
\hline $\begin{array}{l}\text { Treatment } \\
\text { Groups }\end{array}$ & $\begin{array}{c}\text { PCV } \\
\%\end{array}$ & $\begin{array}{c}\text { WBC } \\
\mathbf{X 1 0} / \mathbf{L}\end{array}$ & $\begin{array}{c}\mathbf{R B C} \\
\mathbf{X 1 0} / \mathbf{L}\end{array}$ & $\begin{array}{c}\text { HB } \\
\mathbf{g} / \mathbf{d L}\end{array}$ & $\begin{array}{c}\text { Platelets } \\
\mathbf{X 1 0} / \mathbf{L}\end{array}$ \\
\hline Normal control & $45.00 \pm 4.36^{\mathrm{b}}$ & $6.73 \pm 0.31^{\mathrm{c}}$ & $4.92 \pm 0.16 \mathrm{bc}$ & $16.80 \pm 0.20^{\mathrm{bc}}$ & $5.61 \pm 0.40^{\mathrm{b}}$ \\
$\mathrm{CCl}_{4}$ control & $36.67 \pm 3.06^{\mathrm{a}}$ & $5.73 \pm 0.23^{\mathrm{ab}}$ & $4.83 \pm 0.17 \mathrm{a}$ & $16.20 \pm 0.21^{\mathrm{a}}$ & $3.07 \pm 0.12^{\mathrm{a}}$ \\
$\mathrm{CCl}_{4}+100 \mathrm{mg} / \mathrm{kg} /$ day silymarin & $49.00 \pm 1.00^{\mathrm{b}}$ & $5.13 \pm 0.31^{\mathrm{a}}$ & $4.95 \pm 0.06 \mathrm{c}$ & $17.00 \pm 0.53^{\mathrm{c}}$ & $4.87 \pm 0.31^{\mathrm{b}}$ \\
$\mathrm{CCl}_{4}+100 \mathrm{mg} / \mathrm{kg} /$ day AVSB & $43.67 \pm 8.96^{\mathrm{b}}$ & $6.81 \pm 0.20^{\mathrm{c}}$ & $4.89 \pm 0.24^{\mathrm{ab}}$ & $16.33 \pm 0.23^{\mathrm{ab}}$ & $4.74 \pm 0.10^{\mathrm{b}}$ \\
$\mathrm{CCl}_{4}+200 \mathrm{mg} / \mathrm{kg} /$ day AVSB & $44.32 \pm 3.46^{\mathrm{b}}$ & $6.13 \pm 0.31^{\mathrm{b}}$ & $4.87 \pm 0.09 \mathrm{ab}$ & $17.03 \pm 0.25^{\mathrm{c}}$ & $5.03 \pm 0.25^{\mathrm{b}}$ \\
$\mathrm{CCl}_{4}+500 \mathrm{mg} / \mathrm{kg} /$ day AVSB & $43.56 \pm 1.75^{\mathrm{b}}$ & $5.40 \pm 0.53^{\mathrm{a}}$ & $4.95 \pm 0.08^{\mathrm{c}}$ & $17.04 \pm 0.22^{\mathrm{c}}$ & $5.33 \pm 0.21^{\mathrm{b}}$ \\
\hline
\end{tabular}

Values are presented as mean \pm standard deviation $(n=5)$; Values with different superscripts are significantly different at $\mathrm{P}<0.05$.

\subsection{Effects of AVSB on the liver histomorphology of $\mathrm{CCl}_{4}$ induced rats}

The photomicrograph showing the liver histomorphology of normal control rats in Figure 10a indicated the normal hepatic histology for laboratory rodents. The liver section showed numerous partially demarcated hepatic lobules consisting of hepatocytes arranged in interconnecting cords around the central veins $(\mathrm{V})$. The cords radiate towards the periphery of the hepatic lobule where it meets with the components of the portal areas (P) (Hepatic artery; hepatic vein and bile ductile). The hepatic lobules also showed clear hepatic sinusoids. The liver photomicrograph of the liver from the carbon tetrachloride-induced untreated rats manifested a widespread random area of necrosis with infiltration of mononuclear cells (white arrow) and moderate periportal infiltration of inflammatory leucocytes (black arrow) as shown in Figure 10b. The liver photomicrograph of carbon tetrachloride-induced rats treated with $100 \mathrm{mg} / \mathrm{kg} / \mathrm{d}$ of silymarin in Figure 10c indicated normal hepatic histology of a laboratory rodent with a central vein $(\mathrm{V})$ and portal area $(\mathrm{P})$. However, the liver photomicrographs in Figures 10d and 10e showed the liver histomorphology of carbon tetrachlorideinduced rats treated with 100 and $200 \mathrm{mg} / \mathrm{kg} / \mathrm{d}$ of AVSB respectively. The liver photomicrograph of $\mathrm{CCl}_{4}$ induced rats treated with $100 \mathrm{mg} / \mathrm{kg} / \mathrm{d}$ of AVSB extract showed a mild infiltration of mononuclear leucocytes around the portal areas (arrow) indicated with a letter (P) (Figure 10d). Similarly, the rat liver from $\mathrm{CCl}_{4}$ induced rats treated with $200 \mathrm{mg} / \mathrm{kg} / \mathrm{d}$ of AVSB extract showed multifocal random aggregations of inflammatory leucocytes (white arrow) in the hepatic parenchyma. The letters $(\mathrm{V})$ and $(\mathrm{P})$ represent the central vein and portal area respectively. The liver photomicrograph of a liver section from $\mathrm{CCl}_{4}$ induced rats treated with $500 \mathrm{mg} / \mathrm{kg} / \mathrm{d}$ of AVSB extract showed the normal hepatic histology of a normal laboratory rodent (Figure 10f).
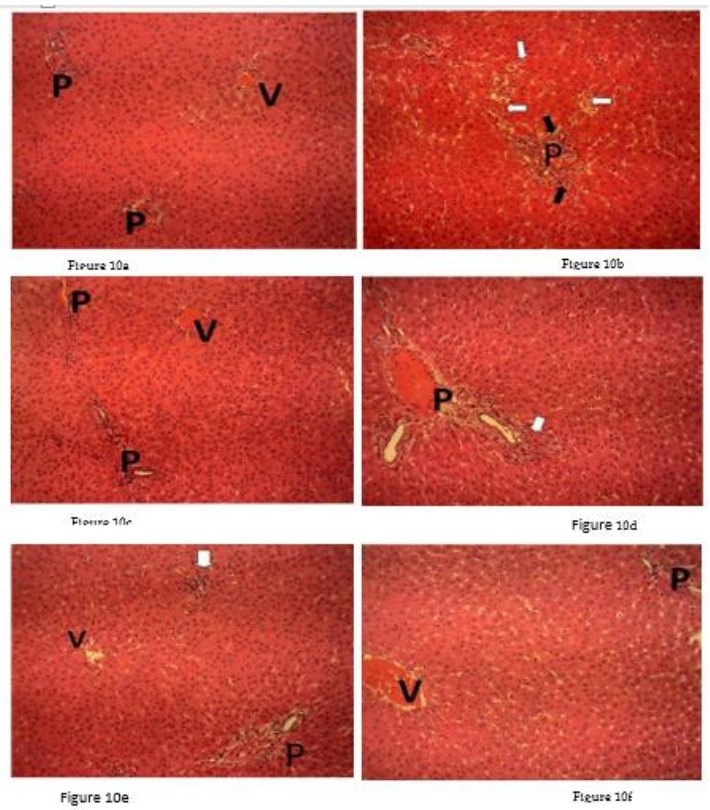

Figure 10. Figures $10 \mathrm{a}-\mathrm{d}$ are the photomicrographs of the liver sections from the normal control, $\mathrm{CCl}_{4}$ control, rats induced $\mathrm{CCl}_{4}$ treated with $100 \mathrm{mg} / \mathrm{kg} / \mathrm{d}$ of silymarin, and CCl4 induced rats treated with 100, 200 and $500 \mathrm{mg} / \mathrm{kg} / \mathrm{d}$ of AVSB respectively. 


\section{DISCUSSION}

This study evaluated the antioxidant composition, in vitro antioxidant activities of AVSB and its hepatoprotective and haematological effects on the $\mathrm{CCl}_{4}$ induced rats. $\mathrm{CCl}_{4}$ is a potent hepatotoxicant that could severely damage the liver and impair its functions because of the toxic effects of highly reactive trichloromethyl $\left(\mathrm{CCl}_{3}\right.$.) and trichloromethyl peroxyl radicals generated from $\mathrm{CCl}_{4}$ breakdown in the body [23] . These reactive free radicals are capable of eliciting lipid peroxidation and oxidative damage to various biomolecules and organs especially the liver that adversely affects the stability, integrity and functions. Medicinal plant extracts rich in antioxidant components are effective in the management of oxidative stress and protecting the liver cells from hepatotoxicants and oxidative damage.

The antioxidant phytochemicals inhibit free radical attack on biomolecules and oxidative damage and could help to prevent the toxic effects of $\mathrm{CCl}_{4}$ on hepatocytes and promote good health. The high levels of antioxidant components including total phenols and flavonoids detected in the AVSB suggest that the extract could be rich in antioxidant properties that would prevent lipid peroxidation and oxidative damage associated with the excess free radical attack on biomolecules. The antioxidant components present in the AVSB could supplement the endogenous antioxidants in preventing oxidative stress and inducing repair of cells and organs damaged by free radicals in line with findings of Jaouad and Torsten [24]. The high flavonoid contents in AVSB could contribute much to its antioxidant activity possibly by chelating reactive metals or by scavenging excess reactive radicals, which prevents oxidative damage and are in line with the mechanism of antioxidant activity earlier suggested [25]. Plant extracts rich in $\beta$-carotene, and lycopene like AVSB possess antioxidant activities to scavenge free radical and reduce oxidative stress-related diseases like various cancer, diabetes, ageing and cardiovascular diseases is in line with the previous findings [26]. Vitamin $C$ is one of the most commonly consumed vitamins that have antioxidant activity due to its ability to donate an electron to reactive free radicals thereby making them stable and help regeneration of vitamin $E$ ( $a$-tocopherol) in the body. Thus, the high content of vitamin C in AVSB could be beneficial in the management of oxidative stress and promote a healthy life. The high levels of antioxidant components in the AVSB could effectively scavenge free radicals and inhibit oxidative damage to biomolecules and injuries to various tissues and organs in the body [25].

The dose-dependent increases observed in the absorbance with the increasing concentrations of the AVSB indicated a reduction of ferric ions $\left(\mathrm{Fe}^{3+}\right)$ to ferrous ions $\left(\mathrm{Fe}^{2+}\right)$ possibly via hydrogen donation from the antioxidant components in the extract. The ferric reducing antioxidant power of AVSB could be attributed to antioxidant components like flavonoids, ascorbic acid, $\beta$-carotene and vitamin E present in large amounts in the extract. The ferric reducing power of the extract was markedly low relative to rutin and vitamin $\mathrm{C}$ respectively suggesting that there may be other phytochemicals present in the extract that inhibit its antioxidant activity. Plant extracts with antioxidant activity like the AVSB have been shown to reduce the risk of oxidative stress associated diseases like diabetes, cardiovascular and neurodegenerative diseases.

The DPPH is a stable radical commonly employed in the investigation of in vitro antioxidant activity of bioactive compounds like flavonoids, phenols, vitamins $\mathrm{C}$ and $\mathrm{E}$ because they can reduce DPPH radical to their respective hydrazine by donating an electron to the unpaired nitrogen atom. It is one of the most reliable means of evaluating antioxidant activities of plant extracts, drugs and foods based on their ability to scavenge free radicals by serving as hydrogen donors. The dose-dependent DPPH radical scavenging activity of the AVSB indicated that the extract possesses significant free radical scavenging activity, especially at higher doses, which are in line with the previous findings [27]. The extract could serve as a potent antioxidant by donating a hydrogen atom to unpaired free radicals like vitamin $C$ and other antioxidant compounds. The lower DPPH scavenging activity demonstrated by the extract at each of the concentrations tested when compared with vitamin $\mathrm{C}$ indicated interference by other phytoconstituents present in the extract. The high IC50 value obtained for the extract relative to vitamin $C$ further indicated that increased doses of the extract are required to achieve effective DPPH scavenging activity comparable to vitamin C.

Nitric oxide is a multifunctional second messenger generated from the conversion of arginine to citrulline by the action of arginine synthase in endothelial cells, neurons and phagocytes. Due to the presence of unpaired electron in nitric oxide, it functions as a free radical and reacts with superoxide radicals to give a very reactive peroxynitrite anion that is highly toxic to the biological system [28]. The nitric oxide plays important physiological roles in the regulation of blood pressure, erection in men and inflammatory reactions but when present in high concentration could induce oxidative stress that damage DNA, membrane integrity, tissues, and organs in line with the report of Dzoyem and Eloff [29]. The dose-dependent increase in the nitric oxide scavenging activity demonstrated by the AVSB could be attributed to its rich antioxidant components 
like flavonoids, phenols, vitamins $\mathrm{C}$ and $\mathrm{E}$ which are in agreement with the previous report that plant extracts rich in flavonoids and phenols are potent scavengers of nitric oxide [30]. The high level of flavonoids, phenols, $\beta$-carotene, lycopene, vitamins C and E present in the AVSB possess redox properties that enable them to function as reducing agents via electron donation and metal chelation. These could be responsible for nitric oxide scavenging and other antioxidant activities exhibited by the plant extract in this study in line with the findings of Pietta [31]. The nitric oxide scavenging activity of the AVSB was lower than curcumin, which suggests that the extract contained other non-antioxidant components that interfered with its antioxidant activity.

The marked increases in the activities of serum hepatic marker enzymes including alanine transaminase (ALT), aspartate transaminase (AST) and alkaline phosphatase (ALP) indicated hepatotoxic effects of carbon tetrachloride $\left(\mathrm{CCl}_{4}\right)$ in the rats induced without any treatment and agrees with earlier findings [32, 33]. The serum ALT, AST and ALP activities are usually insignificant due to their very low concentrations in the extrahepatic environment under normal health conditions and their increased activities occur mainly when there are hepatic injuries. This is because they can easily leak outside hepatocytes due to damaged hepatic membrane and increased permeability. The toxic effects of $\mathrm{CCl}_{4}$ induction caused could have damaged liver injury, compromised liver integrity and architecture and elevated their concentrations and activities in the serum. However, kidney and heart tissues could have contributed to increased AST and ALP activities observed in the rats as $\mathrm{CCl}_{4}$ has shown to have adverse effects on these organs as such their increased activities in the serum are a relatively less specific indicator of hepatic injury, unlike ALT activity.

The dose-dependent reductions in the serum ALT, AST and ALP activities in the $\mathrm{CCl}_{4}$ induced rats treated with silymarin and AVSB respectively showed that AVSB has hepatoprotective effects similar to that of silymarin, which improved hepatic integrity and prevented leakage of these enzymes to the extrahepatic tissues. The reductions of ALT, AST and ALP activities are consistent with the findings that reductions in the activities of the hepatic enzyme of $\mathrm{CCl}_{4}$ induced rats are an indication of recovery from hepatic injury [34]. The treatment with AVSB could have improved hepatic integrity by scavenging reactive free radicals like trichloromethyl and trichloromethyl peroxyl radicals generated from biotransformation of $\mathrm{CCl}_{4}$ in the rats that are responsible for the oxidative stress that damage hepatocytes and impair their functions. The high antioxidant components like phenols, flavonoids, $\beta$-carotene and lycopene could scavenge free radicals, dilute the adverse effects of many oxidants, and not limited to trichloromethyl and trichloromethyl peroxyl radicals. The AVSB possesses hepatoprotective activity comparable to silymarin preferably at higher doses and may as an alternative to silymarin in the management of hepatic disorders. These hepatoprotective effects of AVSB against $\mathrm{CCl}_{4}$ toxicity in rats give credence to its use in traditional medicine for the management of hepatic disorders. However, the major hepatoprotective bioactive principle in AVSB needed to be isolated to enable its full utilization in the management of hepatic disorders and diseases with minimal adverse effects. The elevated hepatic enzymes activities in the $\mathrm{CCl}_{4}$ induced rats treated with a lower dose of AVSB suggest that the extract possesses insignificant hepatoprotective activity at a lower dose and requires administration of higher doses to achieve better hepatoprotective effects and are consistent with the earlier findings [32].

The significant reductions of total protein and albumin concentrations in the $\mathrm{CCl}_{4}$ induced untreated rats could be attributed to the adverse effects of $\mathrm{CCl}_{4}$ toxicity on the hepatocytes and probably the endoplasmic reticulum that impaired their ability to synthesize sufficient amounts of total protein including albumin. Liver cells synthesize proteins including albumin needed to maintain normal biochemical functions in the body and its measurement could be used to monitor liver functions as earlier suggested [35]. The marked elevation in total protein and albumin concentrations of $\mathrm{CCl}_{4}$ induced rats treated with graded doses of the AVSB indicated recovery of the rats from hepatic injury and restoration of hepatic functions, which are in agreement with the previous findings [36]. The extract probably prevented $\mathrm{CCl}_{4}$ metabolites from causing severe oxidative damage to the hepatocytes by antioxidant activity and stimulation of endogenous antioxidants that could have maintained the integrity and functions of the hepatocytes. Albumin plays a vital role in the transport and maintenance of adequate levels of bilirubin, minerals, fatty acid, drugs and some xenobiotic and its increased concentrations in the AVSB treated $\mathrm{CCl}_{4}$ induced rats could be responsible for the low levels of serum total bilirubin recorded in these animals.

The elevated serum total bilirubin levels in the $\mathrm{CCl}_{4}$ induced untreated rats could be attributed to the hepatic injury suffered by the animals that impaired their liver functions and low concentrations of albumin available in these animals to transport bilirubin to the liver for biotransformation and excretion. However, the lower levels of total bilirubin in the $\mathrm{CCl}_{4}$ induced rats treated with graded doses of AVSB indicated hepatic 
recovery from $\mathrm{CCl}_{4}$ toxicity and improved protein synthesis including albumin required to transport bilirubin to the liver for detoxification which in line with findings of Uroko et al., [34].

The significant reductions in the percentage packed cell volume (PCV), haemoglobin (Hb), platelets, red blood cell (RBC) and white blood cell (WBC) counts of rats induced carbon tetrachloride untreated indicated toxic effects of $\mathrm{CCl}_{4}$ on the blood cell which might have caused haemolysis of the blood cells or hindered the ability of bone marrow to produce sufficient blood cells. The reductions in PCV, RBC, Hb, WBC and platelets counts are consistent with previous findings on the haematotoxic effects of $\mathrm{CCl}_{4}$ on the rats [37]. However, the significant dose-dependent increases in the $\mathrm{PCV}, \mathrm{Hb}, \mathrm{RBC}$, and $\mathrm{WBC}$ counts in the $\mathrm{CCl}_{4}$ induced rats treated with the AVSB can be attributed to haematoprotective effects of the effects of the extract. The extract prevented the blood cells from haemolysis and maintained normal bone marrow function and reversed the possible anaemia and insufficient haemoglobin concentration caused by the $\mathrm{CCl}_{4}$ induction in the untreated rats. The improved haematological indices in the $\mathrm{CCl}_{4}$ induced rats treated with AVSB could be attributed to its high levels of antioxidant components like flavonoids, phenols, vitamins $\mathrm{C}$ and $\mathrm{E}$ that ameliorated the adverse effects of reactive $\mathrm{CCl}_{4}$ metabolites on the haematological indices and other tissues in the body as previously reported [38]. However, treated with AVSB reversed the significant decreases in platelet counts of the $\mathrm{CCl}_{4}$ induced rats to normal levels and suggest that the AVSB could prevent blood loss from bleeding.

The wide spread necrosis observed in the liver of the $\mathrm{CCl}_{4}$ induced untreated rats could be attributed to the hepatotoxic effects of $\mathrm{CCl}_{4}$ which are in agreement with the previous findings [4,5]. These findings suggest that the toxic reactive metabolites of $\mathrm{CCl}_{4}$ such as trichloromethy and trichloromethyl peroxyl radicals attacked hepatic cells and caused various degrees of hepatic injury possibly via oxidative mechanism. However, the mild infiltration of mononuclear leucocytes around portal areas and multifocal random aggregations of inflammatory leucocytes in the $\mathrm{CCl}_{4}$ induced rats treated with 100 and $200 \mathrm{mg} / \mathrm{kg} / \mathrm{d}$ of AVSB extract respectively are indicative of the hepatoprotective effects of AVSB extract. The extract was able to prevent $\mathrm{CCl}_{4}$ induced necrosis in the rats but not attain complete protection of the hepatocytes from the toxic effects of $\mathrm{CCl}_{4}$ as the rats suffered mild hepatic injury contrary to the $\mathrm{CCl}_{4}$ induced rats treated with silymarin.

\section{CONCLUSION}

The findings of this study revealed that the AVSB contains high levels of antioxidants including flavonoids, phenols, $\beta$-carotene, vitamins $C$ and $\mathrm{E}$ and exhibits dose-dependent in vitro antioxidant activities as indicated by its ferric reducing antioxidant power, DPPH, and nitric oxide scavenging activities. The AVSB demonstrated hepatoprotective and haematoprotective effects against carbon tetrachloride-induced toxicity and effectively restored normal hepatic integrity and functions and maintained normal haematological indices in the $\mathrm{CCl}_{4}$ induced rats treated with it.

\section{MATERIALS AND METHODS}

\subsubsection{Collection and identification of plant material}

The fresh Anthocleista vogelii stem barks were collected from the botanical garden at the Michael Okpara University of Agriculture, Umudike, Umuahia, Abia State. The stem barks were properly identified and authenticated at the Department of Forestry and Environmental Management, College of Natural Resources and Environmental Management, Michael Okpara University of Agriculture, Umudike, with a voucher number FHI 40448.

\subsubsection{Chemicals and reagents}

The study used high qualities laboratory chemicals and reagents sourced from well-known manufacturers and distributors of high-grade analytical chemicals and reagents. The ethanol was sourced from Sigma-Aldrich (USA), silymarin from Micro Labs Limited (India), carbon tetrachloride from Merck KGaA, Darmstadt, Germany, while other chemicals and reagents were obtained from chemical stores at Onitsha, Anambra State, Nigeria.

\subsubsection{Preparation and extraction of plant material}

The fresh Anthocleista vogelii stem barks were handpicked, washed in running water, sliced into small pieces and dried under shade until they were properly dried. The dried A. vogelii stem bark sample was pulverized into a coarse powder using a milling machine and stored inside a sterile clean dry container. Five hundred grams (500 g) of the coarsely ground Anthocleista vogelii stem barks were soaked in $1.5 \mathrm{~L}$ of absolute 
ethanol for $72 \mathrm{~h}$, filtered with mesh cloth followed with Whatman No. 1 filter paper and the filtrate concentrated in a Water bath at $50^{\circ} \mathrm{C}$ until all the ethanol has evaporated, weighed and percentage yield calculated [10].

\subsubsection{Experimental animals}

Thirty male Wistar albino rats weighing 140 - $150 \mathrm{~g}$ were purchased from the University of Nigeria, Nsukka, Enugu State, Nigeria and acclimatized to the environmental condition at the Animal House of the College of Natural Sciences, Michael Okpara University of Agriculture, Umudike, Abia State. The rats were acclimatized under $12 \mathrm{~h}$ dark/light cycles with unhindered access to standard feed and drinking water ad libitum for 14 days.

\subsubsection{Experimental design for animal study}

The study utilized six groups of rats containing five rats per group. Group 1 was the normal control rats without $\mathrm{CCl}_{4}$ induction but received distilled water $2 \mathrm{ml} / \mathrm{kg} / \mathrm{d}$ for 14 days and group 2 was the $\mathrm{CCl}_{4}$ control that was $\mathrm{CCl}_{4}$ induced but received no treatment. Groups $3-6$ were treatment groups that were $\mathrm{CCl}_{4}$ induced but treated with $100 \mathrm{mg} / \mathrm{kg} / \mathrm{d}$ silymarin, 100, 200 and $500 \mathrm{mg} / \mathrm{kg} / \mathrm{d}$ AVSB respectively for 14 days. On completing the treatment on the $14^{\text {th }}$ day, the rats fasted overnight, blood samples were collected, and livers harvested on the $15^{\text {th }}$ day for biochemical and haematological analyses, and histological examinations respectively.

\subsubsection{Induction of liver injury}

Liver injury was induced in the rats by subjecting the rats to overnight fasting followed by the intraperitoneal administration of $2 \mathrm{ml} / \mathrm{kg}$ (i.e. $2000 \mathrm{mg} / \mathrm{kg}$ ) carbon tetrachloride $\left(\mathrm{CCl}_{4}\right)$ mixed with olive oil in the ratio of 2:1 (v/v) on day 1 and allowed to stay for $72 \mathrm{~h}$ without any treatment to enable $\mathrm{CCl}_{4}$ to initiate sufficient oxidative damage on the liver cells.

\subsubsection{Determination of the antioxidant contents}

The flavonoids and total phenols contents in the ethanol extract of A. vogelii stem bark (AVSB) were determined using the methods described by Harborne, and Trease and Evans respectively [11, 12]. The $\beta$ carotene and lycopene content in the AVSB were determined according to the methods of Nagata and Yamashita while the vitamins $C$ (ascorbic acid) and E (a-tocopherol) contents were quantified using the methods of Omaye et al., and Desai respectively [13, 14, 15].

\subsubsection{Determination of hepatoprotective and haematological indices}

The alanine transaminase (ALT), aspartate transaminase (AST), and alkaline phosphatase (ALP) activities were assayed with the methods of Reitman and Frankel using Randox commercial kits [16]. The total bilirubin was determined using the method described by Jendrassik and Grof [17]. The serum total protein concentration was quantified with the Biuret method as modified by Lubran while the albumin concentration was quantified with the method of Doumas et al., $[18,19]$. The haematological indices including percentage packed cell volume (PCV), haemoglobin concentrations, red blood cell, white blood cell and platelet counts were quantified with an automated haematology Analyzer-MC-2800 (Mindray Company, China).

\subsubsection{Determination of the in vitro antioxidant activities}

The in vitro antioxidant activities including ferric reducing antioxidant power (FRAP), DPPH $(2,2-$ diphenyl-1-picrylhydrazyl) and nitric oxide (NO) scavenging free radicals activities of the AVSB were quantified with the methods of Oyaizu; Hatano et al., and Marcocci et al., respectively [20, 21, 22].

\subsubsection{Ethical issues}

The study was conducted in line with the regulations of the Research Ethics Committee of Iranian Ethical Guidelines for the use of animals in research and the guidelines of the Research Ethics Committee of Michael Okpara University of Agriculture Umudike (MOUAU) for experiments with animals. The ethical clearance was duly approved by the Ethical Committee of the Department of Physiology and Pharmacology, College of Veterinary Medicine, Michael Okpara University of Agriculture, Umudike with the Ethical Number: MOUAU/VPP/EC/18/003" 


\subsubsection{Statistical analysis}

The data obtained from the animal study were statistically analyzed with a Statistical Products and Service Solutions (SPSS) version 22 using one-way analysis of variance and Duncan's multiple range comparison post hoc test (LSD) and the level of statistical significance obtained at $(\mathrm{P}<0.05)$. The results were presented as mean \pm standard deviation $(n=5)$.

Acknowledgements: The authors appreciate Dr. Ibe K. Ndukwe for his contributions to the identification and authentification of the plant sample.

Author contributions: Concept - U.R., N.C.; Design - U.R., A.A., O.J.; Supervision - U.R., A.A.; Resources - A.A., U.R.; Materials - N.C., O.J.; Data Collection and/or Processing - U.R., N.C., O.J.; Analysis and/or Interpretation - U.R., A.A.., O.J.; Literature Search - U.R., A.A., N.C.; Writing - U.R.; Critical Reviews - U.R., A.A., N.C., O.J.

Conflict of interest statement: The authors have declared no conflict of interest.

Ethics committee approval: All experiments conducted in this study were approved by Ethical Committee of the Department of Physiology and Pharmacology, College of Veterinary Medicine, Michael Okpara University of Agriculture, Umudike with the approval number of MOUAU/VPP/EC/18/003.

\section{REFERENCES}

[1] Cullen JM. Mechanistic classification of liver injury. Toxicol Pathol. 2005; 33: 6-8. [CrossRef]

[2] Galicia-Moreno M, Guti'errez-Reyes G. The role of oxidative stress in the development of the alcoholic liver disease. Revista de Gastroenterologia de Mexico. 2014; 79(2): 135-144. [CrossRef]

[3] Sreejayan N, Rao MNA: Free radical scavenging activity of curcuminoids. Arzneimittelforschung. 1996; 46:169-171

[4] Uroko RI, Sangodare RSA, Muhammad KH, Asadu CL. Effect of methanol extract of Abrus precatorius leaves on male Wistar albino rats induced liver damage using carbon tetrachloride. J Biol Sci. 2015; 15 (3): 116-123. [CrossRef]

[5] Mahmoodzadeh, Y, Mazani, M, Rezagholizadeh L. Hepatoprotective effect of methanolic Tanacetum parthenium extract on CCl4-induced liver damage in rats. Toxicology Reports. 2017; 4: 455-462. [CrossRef]

[6] Burkill HM. The useful plants of West Tropical Africa. Vol. 3. 2nd ed. Royal Botanic Gardens, Kew. 1995; 26-33

[7] Christophe M, Frida L, Celine N, Zacharie S, Emilie N, Paul VT. Evaluations of acute and subacute toxicity of stem bark aqueous extract of Anthocleista schweinfurthii (Loganiaceae). World J Pharm Pharm. Sci. 2015; 4:197-208. [CrossRef]

[8] Igoli JO, Ogaji OG, Tor-Anyiin TA, Igoli NP.Traditional medicine practice amongst the Igede People of Nigeria. Part II. Afr J Trad CAM. 2005; 2(2):134-152.

[9] Anyanwu GO, Nisar-ur-Rehman RT, Onyeneke CE, Rau K. Medicinal plants of the genus Anthocleista. A review of their ethnobotany, phytochemistry and pharmacology. J Ethnopharmacol. 2015; 175:648-667. [CrossRef]

[10] Uroko RI, Nwuke CP, Uchenna ON, Asadu CL, Dingwoke EJ, Adamude FA, Nwobodo NN. (2019). Hepatocurative effects of methanol extract of Acanthus montanus leaves on acetaminophen-induced liver failure in rats. Drug Invention Today. 2019; 11(9): 2176-2183.

[11] Harborne JB. Phytochemical Methods: A Guide to Modern Techniques of Plant Analysis. 3rd ed. Chapman and Hall, London. 1998; 88-185.

]12] Trease GE, Evans WC. Pharmacognosy 15 edition. W. B Saunders Company published by Bailliere Tindall. 2002; 197393.

[13] Nagata M, Yamashita I. Simple method for simultaneous determination of chlorophyll and carotenoids in tomato fruit. J Jpn Soc Food Sci Technol. 1992; 39(10): 925-928. [CrossRef]

[14] Omaye ST, Turnball A, Sauberlid HE. Selected methods for the determination of ascorbic acid in cells, tissues and fluids. Meth Enzymol. 1979; 62: 3-11. [CrossRef]

[15] Desai ID. Vitamin E analysis: Methods for animal tissues. Meth Enzymol. 1984; 105: 138-147. [CrossRef]

[16] Reitman S, Frankel S. A colourimetric method for the determination of serum glutamic oxaloacetic and glutamic pyruvic transaminase. Am J Clin Pathol. 1975; 28: 56-63. [CrossRef]

[17] Jendrassik L, Grof P. Determination of total bilirubin. Biochemistry. 1938; 279: 81-89. 
[18] Lubran MM. The measurement of total serum proteins by the biuret method. Ann Clin Lab Sci. 1978; 8(2): 106-110.

[19] Doumas BT, Watson WA, Big GHG. Albumin standard and the measurement of serum albumin with bromocresol green. Clin Chem. 1971; 31: 78-96. [CrossRef]

[20] Oyaizu M. Studies on products of browning reactions: Antioxidative activities of products of browning reaction prepared from glucosamine. Jpn J Nutr Diet. 1986; 44: 307-315. [CrossRef]

[21] Hatano T, Kagawa H, Yasuhara T, Okuda T. Two new flavonoids and other constituents in liquorice root: their relative astringency and radical scavenging effects. Chem Pharm. Bull. 1988; 36: 2090-2097. [CrossRef]

[22] Marcocci I, Marguire JJ, Droy-lefaiz MT, Packer L. The nitric oxide scavenging properties Ginkgo biloba extract. Biochem Biophys Res Commun. 1994; 201: 748-755. [CrossRef]

[23] Zeashan H, Amresh G, Singh S, Rao CV. Hepatoprotective activity of Amaranthus spinosus in experimental animals. Food Chem Toxicol. 2008; 46:3417-3421. [CrossRef]

[24] Jaouad B, Torsten B. Exogenous antioxidants-Double-edged swords in cellular redox state. Oxid Med Cell Longev. 2010; 3 (4): 28-37. [CrossRef]

[25] Pandey AK, Mishra AK, Mishra A. Antifungal and antioxidative potential of oil and extracts derived from leaves of Indian spice plant Cinnamomum tamala. Cell Mol Biol. 2012, 58:142-147.

[26] Lowe, GM, Booth LA, Young AJ, Bilton RF. Lycopene and $\beta$-carotene protect against oxidative damage in HT29 cells at low concentrations but rapidly lose this capacity at higher doses. Free Radic Res. 1999; 30:141-151. [CrossRef]

[27] Majewska M, Skrzycki M, Podsiad M, Czeczot H. Evaluation of antioxidant potential of flavonoids: an in vitro study. Acta Pol Pharm. 2011; 68(4): 611-615.

[28] Nagmoti D.M, Khatri DK, Juvekar PR, Juvekar AR. Antioxidant activity and free radical-scavenging potential of Pithecellobium dulce Benth seed extracts. Free Radic Antiox. 2011; 2(2): 37-43. [CrossRef]

[29] Dzoyem JP, Eloff JN. Anti-inflammatory, anti-cholinesterase and antioxidant activity of leaf extracts of twelve plants used traditionally to alleviate pain and inflammation in South Africa. J Ethnopharmacol. 2015; 160:194-201. [CrossRef]

[30] Valko M., Morris H, Cronin MTD. Metals, toxicity and oxidative stress. Curr Med Chem. 2005; 12(10): 1161-1208. [CrossRef]

]31] Pietta PG. Flavonoids as antioxidants. J Nat Prod. 2000; 63: 1035-1042. [CrossRef]

[32] Ohwokevwo OA, Ogunka- Nnoka CU. Effect of Ethanol Leaf Extract of Spilanthes filicaulis on Liver Indices and Selected Biochemicals on Carbon Tetrachloride Induced Hepatic Damage in Wistar Rats. J Medicinal Aromat Plants. 2019; 8: 342. [CrossRef]

[33] Uroko RI, Adamude FA, Egba SI, Ani CC, Ekpenyong JE. Hepatoprotective effects of methanol extract of Acanthus montanus (Acanthaceae) leaves on acetaminophen-induced liver injury in rats. PharmacologyOnline 2020; 1: 248-260.

[34] Runzhi Z, Guofang Z, Yinqin C, Qingyu Z, Bin L, Jie L. Oroxylin A accelerates liver regeneration in $\mathrm{CCI}_{4}$-induced acute liver injury mice. PLoS One. 2013; 8:e71612. [CrossRef]

[35] Asadollahi A, Sarir H, Omidi A, Torbati MBM. Hepatoprotective potential of Prosopis farcta beans extracts against acetaminophen-induced hepatotoxicity in Wister rats. Int. J Prev Med. 2014; 5 (10): 1281-1285. [Crossref]

[36] Yang L, Wang CZ, Ye JZ, Li HT. Hepatoprotective effects of polyprenols from Ginkgo biloba L. leaves on CCl4-induced hepatotoxicity in rats. Fitoterapia. 2011; 82(6): 834-840. [CrossRef]

[37] Saba AB, Oyagbemi AA and Azeez OI. Amelioration of carbon tetrachloride-induced hepatotoxicity and haemotoxicity by aqueous leaf extract of Cnidoscolus aconitifolius in rats. Niger J Physiol Sci. 2010; 25: 139-147.

[38] Weber LWD, Meinrad B, Andreas S. Hepatotoxicity and Mechanism of Action of Haloalkanes: Carbon Tetrachloride as a Toxicological Model. Crit Rev Toxicol. 2003; 33(2): 105-136. [CrossRef] 